\title{
The Genogram in Helping Relationship
}

\author{
Lejda Abazi, PhD Cand. \\ Faculty of Human Sciences, Department of Education \\ "Ismail Qemali" University of Vlora
}

\section{Abstract}

The Genogram is a graphical tool used by family therapists to systematize the chronologically and the composition of the family in question and parental relationships within it. The family therapist draws the genogram of the family and analyzing it as a team, draws on assumptions and dysfunctional aspects of strategic solutions that will then occur in session. The Genogram certainly draws from the idea of genealogical tree, but its attribution of authorship is clearly not shared. According to Anne A. Shutzenberger [1], for some it is traced back to Genososciogramma Henry Collomb, from genealogy (family tree) and Sociogram (representation of links and relationships), which he developed in Dakar and exhibited in Nice in 1978, starting from the reflections JL Moreno; for others it is traced back to Murray Bowen (referring to the conference on family therapy in 1967) and then to the conceptualization of the Group of Palo Alto [2] in California. In fact, for both processing paths of the genogram, distances seem shorter epistemological finding themselves in a ring of union in Frieda Fromm-Reichman, the first researcher who started filming family sessions with schizophrenic patients in 1948, and that in 1956 has worked with Moreno in Stanford [3] writing a book with him for four hands [4], with which the Group of Palo Alto [5], marking the birth of the Family Therapy. In truth, says still Shutzenberger, the genesis of Genogram seems to be rooted in the oldest soils, contains itself the concepts of "das Umbewusste" and "Collective Psyche" by S. Freud, and of "collective unconscious" of CG Jung.

Keywords: genogram, helping, relationship

\section{Introduction}

\section{The genogram as a graphical tool in psychotherapy}

Referring elsewhere the very interesting insights into the origins of the technique Genogram, let's jump in the uses that have been documented over time, noting that so far has always spoken of the genogram built by the therapist and the patient, based on the data acquired in session. Later, they were tempted uses more complex the genogram, as was the case in the Family Life Space [6] and the Test of Double Moon [7], but failed to respond fully to the reflections offered by Montagano [8] looking like " the drama inherent in the practice of drawing the genogram, offering live performances and complex, recalling the emotional and affective components of family relationships as have been experienced in that moment, "but also as" the use of the genogram is limited to ... Its use as a technique, while ... the genogram has much broader options, so it can be considered as an expression of therapy. " Indeed E. Lemaire-Arnaud [9] writes, that scheme and graphic form of the genogram "visually reflect the relationships among the true members" and that "everyone has a genogram his writing, absolutely original" because "the geometric pattern becomes free drawing" . Finally, we collect the invocation of Cigoli V. [10] for a "genogram as a multifaceted tool, detached from the history, that activating the system of emotional memory and imagination foster awareness about their inner family". The method presented here Genogram meets these invocations, making the genogram a useful tool that speaks of the "inner family", informs the relational dynamics within it and go into therapy as a means of empowerment.

The method requires that the patient has to draw their own genogram, according to specific criteria of data delivery from the therapist, and at certain times of the therapeutic. In addition, it is taking advantage of the interpretative aspects of the graphic design, which have been verified the basic criteria for a symbolic translation of generalized design genogram made by the patient. It turns out that is used as a test chart that gives the therapist projectively additional information, or confirmation, of certain aspects of the situation. When the end of the therapy or in significant moments of this, the patient is given the second delivery of design your own genogram, this also acquires the meaning of a projective test chart to check the quality of therapeutic change, whose reading is completed by comparison, in the session, with-and for-the patient, of the two graphs which he performed in different treatment times. In fact, the comparative reading of the two graphs drawn 
from the patient, the beginning and end of the therapy, clearly defines the start point and the end point of its path therapeutic. Defines "from where we started "and" where we are ". Useful information for the therapist, who already have one more tool to take stock of the situation on the path to that point made, may decide, alone or in team's work, whether and how to continue therapy (therapy over and leave, partial objective reached, the definition of the next target, readjustment of the therapeutic strategy, etc.), basing their thoughts on data objectified, and not least, the information is useful for the patient, through the joint work of interpretation of this comparison , "fixed" an essential moment of self-awareness, because this process allows him to "objectify", to "see outside themselves" in concrete, black and white, its changes. Even it allows him to read, interpret, and setting a before and an after (clear, recognized and shared), can add to his evolutionary experience a new self-awareness and its history: in the two pictures of before and after, put before his eyes, he will embrace in one glance the entire journey made in therapy and become master of his change. Its changes are real, they are there in front of him, black and white, can be reflected in them, and he was responsible, under the guidance and with the help of psychotherapy. In clinical trials conducted were actually found, in two different graphical representations, significant changes in relation to the therapeutic change reached. It was verified that this change over time, in graphic-symbolic representation of the genogram, is actually the result of a new representation of his familiar world, a reflection of a different picture of his family (and then a relational self, both affective and cognitive ), the result of a new concept of its family graph that the person has built up in his mind, by virtue of a therapeutic change that, thus, can be verified qualitatively and shared with the patient being treated. The idea of starting, then, to check whether the use of the design of the genogram made by the patient could make sense as a graphical tool for verification of therapeutic change, and that is, from the point of view not only systemic changes relational, or rather, the subjective view and relationship that the person has of himself and of his family and affective world, was given positive feedback. Currently research opens to the structuring of a project that leads to a statistically significant validation of the quality results obtained so far. In conclusion, let's look at the genogram as a true therapeutic resource, a revolutionary instrument, a kind of graphic process of verification carried out along the time axis, causing him to compose the patient at the beginning and end of the course of treatment, or in any case necessary, but avoiding a counterproductive familiarization by the person. In fact, repeated use or too close, there are decided reserves. E 'preferable that it remains a tool projective quite unknown to the person. If it becomes mistress, she is likely to become for her as a game and losing its emotional intensity and commitment to design it. It should not be like the thermometer, used at every hint of fever! Obviously, the interval between the two application follows the duration and course of the therapy, but it was observed that in any case is almost never before one year, unless it is not concluded before or not attained, before changes so significant to mark the beginning of a new phase in the course of treatment, and therefore it is worthwhile to "fix".

In fact, the first chart is not commented on in the session, and this does not give way to the person to preserve a special memory. The first chart is only a test of the state of art that informs the current state. The therapist will translate it, sitting outside, according to the reference model and then read it comparatively with this and then play, then it will simply be stored in the folder, and then be taken up during the meeting of delivery of the second graph, for a comparative reading made with the patient in the final session to leave.

\section{The Genogram "Meter Reading for Ombudsman and Family Counseling"}

Family mediation for "systemic-relational" view is somewhat 'more complex and detailed than other schools of thought; in this school we can actually find:

- People who want to redefine their identity within their family;

- People who want to negotiate issues related to separation or any already underway, so happen anyway

as serenely as possible for themselves and their children;

- People who want to learn to communicate with each other to make themselves understood and in turn

understand the other, or simply they wish to start to do so, because by the time they stopped.

- parents who are overwhelmed by events such as the birth of a son, who inevitably it involves new roles

within the family, new tasks, new responsibilities; 
- parents who are struggling to understand the language of their children, who feel light years away from

them as mentality, as the ideal ...;

- Parents who are raising children with a handicap and problems of various kinds.

How many times it is repeated: the mediator or counselor doesn't psychoanalyze the person who addresses him, but it helps to help themselves, to find within itself the means to resolve the conflict alone. To do this sometimes also uses the $\mathrm{cd}$. Genogram, which is similar to a family tree, but is limited to the figures that are considered important by the person at that time, or who have been in the past, figures with whom he feels he still has a relationship, or a broken link, or union ambiguous, perverse, destructive to themselves. The genogram helps to understand, in the case of separation, who can help former spouses in the new situation, in respect of minor children and not only, but can also be a tool to understand the reason why he never communicated, or It stopped doing it, to interpret their actions, their sayings and especially their unspoken, in the light of forgotten incidents or persons who are or have been part of his life even for a short distance. This does not mean that the broker, in case you know it, that the people who stand in front servant couple therapy, a psychologist, a psychotherapist, a sexologist, ..., do not do this, leaving this industry expert the resolution of a problem: the point is that helped them to become aware, for the first time. The practice of the genogram is used as a "bridge" between the past and present emotional and as a vehicle for the future decision.

The graphical representation of the family tree is designed to enhance their family roots, a way to "feel belonging" to identify and define themselves as part and product of a tree with firm roots in history. The family tree is only graphical representation objective; it is a tool for the clarification of the subjective that happens, however, with the genogram refers to the irrational aspects of the people and the relationships between them. The genogram helps the person to realize myths, secrets, roles, beliefs, climate (hot / cold) certain "aspects" of the race and how they influenced the perception that the person has of himself. This work has a goal that invests in the future: to become aware of the perception you have of your own family history "decide" on their "being in the world". In working with the Genogram there are elements that can be learned and possibly explored. First of all, the myth (or myths) family. The original meaning of mithos1 refers to "legend, fairy tale, story"; it obeys the function to protect and reassure the elements of a social group. The myth thus becomes a structure of values, support and validation for behavior as it is something that is already in the history of the family and on which structure the identity of the individual and the group. They must be seized rules that the family has handed down, that is, that set broad standards that the family has been given and that is affected by the vicissitudes and culture. If the rules are broken then the family may decide to make it secret. It is therefore a "gray area" made of vicissitudes, the events on which the family has decided to roll out the silence. Sometimes the secret covers events that may well be revealed but now that you are structured in memory and oblivion. Become aware of the secret can mean dealing with a vision of reality that may be different from the message of the secret and that can help you consider other aspects of self. It is interesting to notice the roles embodied in the family system: in addition to the master role (child, brother, etc.) And the individual (what a person you choose to interpret) there is "relational" 2 that according Montavano-Pazzagli is that the system assigns to the family member and that "depends on the dynamics of relationships and the evolution of relations within the same system" whereby a child can play this role but by birth, if the father dies or becomes absent, may also assume the role of relational father ( for the other brothers) or the husband to his mother. Do you work on an objective reality of family history but on the perception that everyone has it. In this sense, it would not be unusual for two brothers who make a session of genogram are aware of situations "different" while belonging to the same family. Work on the genogram is based on taking the person's awareness of their family roots and, above all, of what it perceives to these roots. The methodology is that of helping relationship in which the broker and / or counselor helps a person in the grip of awareness through clarifying questions, references, reformulations, feelings, impressions that the customer / user can adopt and which can guide you in the exploration. The genogram can be implemented in a group, in a setting individual, family or couple.

\section{LITERATURE}

Ackerman N., Psicodinamica della vita familiare, Bollati Boringhieri, Torino, 1968

Andolfi M., Manuale di psicologia relazionale, A.P.F., 2003

Bateson G., Verso un'ecologia della mente, Adelphi, Milano, 1972/1976

Bertrando P., Toffanetti D., Storia della terapia familiare. Le persone, le idee, Cortina, Milano, 20 
Boszormenyi-Nagy I., Spark G.M., Lealtà invisibili, Astrolabio, Roma, 1988

Bowen M., Dalla famiglia all'individuo. La differenziazione del sé nel sistema familiare, Astrolabio, Roma, 1979

Fivaz-Depeursinge E., Corboz-Warnery J., II triangolo primario, Raffaello Cortina, Milano, 2000

Framo J., Terapia intergenerazionale, Raffaello Cortina, Milano, 1996

Malagoli Togliatti M., Telfener U., Dall'individuo al sistema, Bollati Borighieri, Torino 1991

Minuchin S., Famiglie e terapia con la famiglia, Astrolabio, Roma, 1976

Stern D., II mondo interpersonale, Bollati Boringhieri, Torino, 1987

Stern D., La costellazione materna, Bollati Boringhieri, Torino, 1995

S. Montavano, A. Pazzagli, II Genogramma, FrancoAngeli, Milano, 2002

S. Montavano, "Le drapeau et le puvoir «, in Therapie familiale, 1985

Ugazio V., La costruzione della conoscenza, Franco Angeli, Milano, 1988

Whitaker C., Considerazioni notturne di un terapeuta della famiglia, Astrolabio, Roma, 1990

[1] Schutzenberger A. A. (1993), La sindrome degli antenati, ed. Di Renzo, Roma, (pp. 17-31).

[2] G. Bateson, J. Haley, D. Jackson, poi P. Watzlawick, V. Satir.

[3] presso il Center for Advanced Study in The Behavioral Sciences, dal 1955 al 1965.

[4] Fromm-Reichmann, F., Moreno, J.L. (1956), Profress in Psychotherapy, Grune \& Straton, N.Y.

[5] è da questo gruppo che poi nasce il MRI (Mental Research Institute) dove attualmente lavora Paul Watzlawick con Diana e Louis Everstine et al.

[6] Bozzoli, C., Tamanza, G. (1998), Family Life Space. L'analisi metrica del disegno, FrancoAngeli ed., Milano.

[7] Greco, O. (1999), La doppia luna. Test dei confini e delle apparenze familiari, ed. Vita e Pensiero, Milano.

[8] Montagàno,S., Pazzaglia,A. (1989), II genogramma. Teatro di alchimie familiari, FrancoAngeli ed., Milano, pp.29-30.

[9] Lemaire-Arnaud, E. (1985), Utilitè du genogramme pour la mise au jour des phénomènes transformationnelles, in Dialogue, $n^{\circ} 89$, p. 152.

[10] Prefazione, in O. Greco, 1999, pp. 18-19. 